\title{
Detention of Asylum Seekers in Mexico
}

\author{
Gretchen Kuhner
}

\begin{abstract}
Mexico ratified the Convention relating to the Status of Refugees and the 1967 Protocol in April 2000. While Regulations establishing a mechanism for eligibility determination were issued at the same time, the Mexican government began a transitional process to take over eligibility in March 2002. Prior to that time, the UNHCR had been recognizing refugees under its mandate. As of this writing no national policy regarding the detention of asylum seekers has been established, nor have refugee advocates begun to pressure the government to comply with Article 31 of the Convention.

Rather, whether an asylum seeker is detained during the eligibility process depends in part on the place and timing of the request as well as on the knowledge and goodwill of the migration authority.
\end{abstract}

\section{Resume}

Le Mexique a ratifié la Convention des Nations Unies relative au statut des réfugiés et le Protocole de 1967 au mois d'avril 2000. Alors que des règlements établissant un mécanisme pour déterminer l'admissibilité ont été émis au même moment, le gouvernement mexicain a mis en place un processus transitionnel visant à prendre en charge l'admissibilité en mars 2002. Jusqu'à cette date, c'était la HCR qui, comme partie de son mandat, s'occupait de la reconnaissance du statut de réfugié. À l'heure de la rédaction du présent article, une politique nationale de détention des réfugiés n'avait pas encore été établie, et les défenseurs des réfugiés n'avaient pas non plus commencé à faire pression sur le gouvernement pour qu'il se conforme à l'article 31 de la Convention. Au contraire, qu'un réfugié soit détenu ou non durant le processus d'admissibilité dépend en partie du lieu et de l'heure de la demande, aussi bien que du niveau de connaissance et de la bonne volonté de l'agent de l'immigration.

\section{Introduction}

卫 he situation for asylum seekers in detention in Mexico at the time of this writing is in turmoil due to procedural changes in the asylum process that began in March 2002. These changes are a result of the government's new policy of adjudicating asylum claims, rather than accepting the eligibility determinations of the United Nations High Commissioner for Refugees (UNHCR). This is the first such procedural modification since the UNHCR signed an accord de siege with the Mexican government in October 1982 and began recognizing refugees under its mandate. It represents the Mexican government's commitment to begin implementing the 1951 Convention relating to the Status of Refugees and the 1967 Protocol ratified in April 2000 as well as the Regulations to the General Law on Population (Regulations) that were issued at the same time. By bringing asylum procedures into compliance with the existing legal framework, the Mexican government will have the option to continue to detain asylum seekers while their applications are pending or to create a new policy. This article describes the current legal framework for asylum procedures and detention, and follows with a description of the current situation in practice and future challenges.

\section{Background}

Mexico has a long tradition of providing asylum, most notably to exiles during the Spanish Civil War, to persons fleeing the dictatorships in Argentina and Chile, and to Central American refugees during the 1980s to mid-1990's. This tradition is supported by a comprehensive Mexican asylum framework. For example, Mexican law provides for diplomatic and territorial asylum as well as establishing a separate definition for refugees. ${ }^{1}$ Mexico is also a signatory to various regional instruments. ${ }^{2}$ In fact, the current definition of refugee contained in the General Law on Population is based on the definition from the Cartagena Declaration on Refugees of $1984 .^{3}$ 
The current asylum situation is marked by a small number of refugees who, in their majority, utilize Mexico as a route to reach other countries. Many of these refugees come from outside the Latin American region, do not speak Spanish, and have been forced to resort to international agents to help them surmount travel restrictions. In 2001, for example, the 161 refugees recognized in Mexico represented nationals from Albania, Algeria, Bangladesh, Byelorussia, Colombia, Congo, Cuba, Ethiopia, Guatemala, Honduras, Iran, Iraq, Pakistan, Palestine, Russia, Sierra Leone, Sri Lanka, Somalia, Sudan, Togo, Tunisia, and Yemen. ${ }^{4}$ Fewer than half (seventy-seven) originated from countries in the region (Colombia, Cuba, Guatemala, and Honduras). This may change if the situation in Colombia continues to escalate, but has been the pattern for approximately the last six years.

As most refugees traveling through Mexico do not wish to request asylum here, but rather to reach the United States and Canada, it is believed that the UNHCR and the Mexican National Migration Institute (INM) $)^{5}$ come into contact with few of the people who have valid refugees claims. Rather, these organizations come into contact with asylum seekers after they have been apprehended or are being held in detention centres, and are facing the choice of applying for asylum or being deported to their country of origin.

For example, in 2001, of 436 applications filed with the UNHCR, 71.3 per cent were presented by asylum seekers in the Mexico City detention centre. ${ }^{6}$ INM officers referred many other applicants to the UNHCR office from the INM regional offices in Tabasco, Campeche, Chiapas, and Veracruz. Several officers have been trained by the UNHCR to screen apprehended migrants, and in many cases officials have worked with the UNHCR on an ad hoc basis to provide travel documents so that applicants can reach Mexico City for their asylum interview. While there is no reliable data regarding the most common routes for asylum applicants, it is believed that the majority enters Mexico through the southern border with Belize and Guatemala, or by sea through Veracruz, Chiapas and Oaxaca. ${ }^{7}$

\section{Asylum Applications Presented to the UNHCR}

\begin{tabular}{ccccc} 
Year & $\begin{array}{c}\text { Number of } \\
\text { Applications } \\
\text { Detention Centre }\end{array}$ & $\begin{array}{c}\text { Applications } \\
\text { made from }\end{array}$ & $\begin{array}{c}\text { \% of Applications } \\
\text { made from }\end{array}$ & $\begin{array}{c}\text { Total } \\
\text { Dumber } \\
\text { Detenten Centre }\end{array}$ \\
\hline 2000 & 280 & 176 & $62.8 \%$ & 77 \\
2001 & 436 & 311 & $71.3 \%$ & 150
\end{tabular}

* The remainder of the cases were denied, closed, or pending at the beginning of the following calendar year. This number does not include family reunifications.

Source: UNHCR Regional Office Mexico City
In the past, the UNHCR did not seek the release of asylum seekers in detention during the application process because acquiring legal custody was too risky should applicants abandon their claims. This policy was partially based on the fact that between 70 and 80 per cent of recognized refugees "spontaneously resettle" to other countries within one year of receiving refugee status. ${ }^{8}$ Advocates recognize that integration is extremely difficult in Mexico for refugees from outside the region due to language barriers, discrimination, scarce employment opportunities, and lack of ethnic communities fundamental to the orientation process.

Until March 2002, asylum seekers who were detained prior to presenting an application for refugee status endured between one and five months in detention in the Mexico City migrant detention facility while UNHCR protection officers prepared their cases and deliberated them during the weekly eligibility committee meetings. Asylum seekers could face many more months in detention if the UNHCR denied refugee status while they either appealed their case (to the same eligibility committee), or waited for the INM to deport them to their country of origin or to release them with an exit order. ${ }^{9}$

As the government has recently decided to take over the asylum process, it is assumed that the ad hoc procedures of the past will slowly fade while authorities begin to utilize the existing legal framework.

\section{Legal Framework for the Detention of Asylum Seekers in Mexico \\ Eligibility Process}

Mexico ratified the 1951 Convention relating to the Status of Refugees and the 1967 Protocol in April 2000, and issued regulations with new asylum procedures one day later. These regulations contain a strict fifteen-day application deadline. ${ }^{10}$ Once the application has been submitted to the INM local or regional office, it must be forwarded to the central offices in Mexico City, where it is then presented to the Eligibility Committee. This Committee consists of the Vice Minister for Population, Migration and Religious Affairs, and representatives from the Ministry of Foreign Affairs, the Ministry of Labor, the Mexican Commission for Refugee Aid (COMAR), ${ }^{11}$ and the INM. ${ }^{12}$ In addition, the Committee may invite a representative of the UNHCR and representatives of other organizations to participate. The UNHCR and other representatives may participate in the deliberations, but are not granted voting rights. ${ }^{13}$ The Eligibility Committee issues an opinion that is sent back to the INM to be ratified or rejected. According to the time frames established in the Regulations, the total period from 
the moment the application is presented to resolution of the asylum case is a maximum of thirty days.

If the asylum application is denied, the law provides for administrative review by the INM adjudicating officer's superior. ${ }^{14}$ If the administrative review (recurso de revisión) results in a negative decision, the refugee applicant has the option to appeal to the Federal Tribunal for Fiscal and Administrative Justice (Tribunal Federal de Justicia Fiscal y Administrativa), an independent judicial court. ${ }^{15}$ If this decision is contrary to law, the applicant can present a constitutional lawsuit (amparo). ${ }^{16}$ The addition of the Federal Tribunal for Fiscal and Administrative Justice has only been in place since January 1 , 2001, and has not been utilized in refugee cases, as the UNHCR was still in charge of eligibility determination. Depending on the specific situation, the legal system allows the applicant to decide whether he or she will file a constitutional lawsuit against the administrative act or against the judicial decision of the administrative tribunal.

One caveat in the due process guarantees is article 33 of the Mexican Constitution, which provides that migrants whose stay is considered "inconvenient" 17 may be deported without a hearing. However, in practice, an asylum seeker should not be deported until having exhausted all legal recourses.

\section{Detention of Asylum Seekers}

INM officials as well as other law enforcement authorities participate in the apprehension of asylum seekers who do not have proper travel documents. According to the Regulations, an asylum seeker must present the application within fifteen days of having entered Mexico at the closest INM Office. ${ }^{18}$ Once the application has been presented, article 166 of the Regulations allows the INM authority to "take the necessary measures to ensure that the applicant remains at his or her disposition."19 However, as of this writing, it is unclear what those measure will be.

The measures for asylum seekers combine with article 73 of the General Law on Population authorizing federal, state, and local law enforcement officials to collaborate in the arrest of migrants in general. ${ }^{20}$ All migrants who are detained by nonimmigration authorities should be transferred to the nearest migration office for further processing. If the migrant is from a country other than those in Central America, he or she should be transferred to the Mexico City detention centre after initial processing. ${ }^{21}$ This may take several days depending on the place of detention. Migrants may be temporarily housed in local jails, INM offices, or the twenty-five migration detention centres throughout the country.

Before March 2002, if an asylum seeker presented the application to the UNHCR office before entering into the detention process, he or she would be released into UNHCR custody. However, if the detention based on undocumented status or other migration violations occurred before the appli- cation was presented, the applicant would be transferred to the Mexico City detention centre and remain in detention during the interview and review process.

During this transitional period, it is likely that if the asylum seeker is apprehended before presenting the application, he or she will continue to be transferred to the detention centre in Mexico City. However, asylum seekers from Central American countries who face rapid deportation procedures directly to the border from the various regional INM offices will need to assert their right to request asylum. While the UNHCR has made an effort in recent years to train INM personnel, particularly in southern Mexico, there is no general knowledge of refugee issues and no formal procedures for screening migrants for potential refugee cases.

\section{Protections for Detained Asylum Seekers}

Alternatives to detention. The General Law on Population authorizes the INM to grant custody to individuals and non-governmental organizations at its discretion. However, because many migrants, including asylum seekers, are attempting to reach other countries, organizations are wary of accepting the legal obligation. ${ }^{22}$ Until March 2002, Sin Fronteras and the UNHCR monitored the physical and mental health of detainees and made custody requests when the detainee's health was at risk. Accommodation was then provided by these organizations. In some cases, refugee applicants in Comitán Chiapas were released in custody to the UNHCR Chiapas office and remained in a shelter until the UNHCR office in Mexico City had reviewed their application. Asylum seekers who had not been detected by INM or who possessed a tourist visa could remain in the migrant shelters throughout Mexico, particularly along the southern and northern borders. While there are no migrant shelters in Mexico City, Sin Fronteras maintains service agreements with several religious shelters where vulnerable applicants could stay during the eligibility process.

Independent review of the detention decision. In theory, an asylum seeker should have access to independent review through the same administrative proceeding and constitutional procedure described above. There has not been a judicial decision specific to migration law to determine whether administrative detention for longer than thirtysix hours is legal. In January 2001 the Federal Tribunal for Fiscal and Administrative Justice was empowered to hear these cases, yet it is unclear what results these changes will bring. These venues may have to be utilized now that the government is in the process of taking over asylum procedures. 
Limits on period of detention. New regulations for detention centers were published in the Federal Registry (Diario Oficial de la Federación) on November 26, 2001. According to article 7 , the general rule is that detention cannot exceed ninety days. However, there are fifteen exceptions, including "any other reason duly justified by the Coordinator of Migration Control and Verification." ${ }^{23}$ Another reason includes a request by national or international organizations. ${ }^{24}$ Although there is a Supreme Court decision establishing that administrative arrest shall not exceed thirty-six hours, in practice INM officers prolong the detention for extended periods arguing that "arrest" is not the same as "aseguramiento" (administrative detention).

Periodic review of detention. According to the new detention regulations, the INM must resolve the legal situation of the detained migrant in no more than fifteen working days. ${ }^{25}$ While it is not regulated, a committee within the INM meets periodically to review the cases of detainees who have been in detention for more than three months. ${ }^{26}$ Due to lack of consular representation and, in some cases, consular co-operation, the INM has a difficult time obtaining identity and travel documents for some nationalities. The Mexican Constitution provides for judicial review in cases of wrongful detention, but in practice it is unlikely that such a case would have a positive outcome, as the General Law on Population allows for the detention of undocumented asylum seekers.

Access to government-funded legal aid. There is no statefunded independent legal aid for asylum seekers. Under the UNHCR procedures, interviews were "non-adversarial." Under the new procedure, NGOs will need to observe the interview and eligibility process to evaluate whether asylum seekers require representation.

Vulnerable groups. Unaccompanied minors should be assisted by the Department of Family Integration (Departamento de Integración Familiar) and held in its custody throughout the asylum proceeding. In practice, there have been no asylum requests from unaccompanied minors in recent years. Minors accompanied by their mothers are detained in the women's section of the detention centre. On occasion, the UNHCR requested custody of the mother and children so that they could remain in a shelter during the application process.

Interview conditions. UNHCR staff personally interviewed all asylum seekers in a private room. If an interpreter was needed, the UNHCR provided one. This could prolong the process, as it is difficult to find interpreters for some languages in Mexico City.

The UNHCR ensured that all female applicants or female family members of applicants were interviewed individually. The UNHCR provided female interviewers for female asylum applicants and, when possible, female interpreters. These procedures are not expected to change in the short term as COMAR personnel are conducting interviews with UNHCR consultation.

\section{Physical Conditions of Detention}

Information provided by the INM shows that twenty-five immigration detention centres exist in Mexico. Only one, the Mexico City centre, is considered a long-term detention centre, while the others are located within Immigration Offices and are used to process migrants within several days. Those migrants that can be deported to Guatemala through the bilateral agreement are returned directly to that country, while migrants of all other nationalities are transferred to the Mexico City centre for further processing and consular access. In 2001, the INM began deporting some extra-regional migrants to Guatemala, rather than deporting them to their country of origin. ${ }^{27}$ No bilateral agreement exists between Mexico and Guatemala that allows this procedure.

While some information is available regarding detention conditions for migrants in the Mexico City centre, virtually no systematic information has been obtained on the other centres. ${ }^{28}$ Several articles have documented irregularities in basic procedural guarantees including corrupt practices as well as physical conditions that violate basic human rights standards. ${ }^{29}$ One problem is consistent overcrowding of the centre, particularly in the male section. The centre has a 140-person capacity, while the men's section frequently houses over four hundred detainees. As a result, people are forced to sleep on the floor in rows along the hallway. This situation has exacerbated hygiene problems including soiled and flea-infested mattresses and blankets and skin irritations. Overcrowding has also prompted disruption of recreational activities, escalating tension among the detained population and, on occasion, led to riots. Other common complaints among detainees include lack of potable water (causing dehydration and gastrointestinal disorders) and inadequate medical attention.

Another problem concerns accusations of sexual harassment in the women's section. While the detention regulations require female personnel in the women's section, detainees have reported the presence of male officers on a regular basis. Women have also complained about the lack of female medical personnel.

Complaints of physical and verbal abuse have also been reported, but not well documented. The Mexican NGO Sin Fronteras began to offer pro bono legal representation to detained migrants in February 2002. In this short time, the legal advocate has documented three cases of physical 
abuse, including the case of a man who was severely beaten by an INM official, leading to the loss of three teeth, among other injuries.

The INM has responded to these complaints by promising to remodel the facilities, to improve hygiene conditions, and to train INM officers in human rights practices. In August 2001, the INM announced plans to enlarge the facilities increasing capacity to 396 . To date, the construction has not been completed.

\section{Current Procedures}

As of this writing, the COMAR has been presiding over an ad hoc Eligibility Working Group for approximately one month. The UNHCR and Sin Fronteras still participate in the meetings and have maintained voting rights during this transitional process. Refugees who receive a positive decision are placed in custody of the COMAR and given a letter stating that their migration documents are in process. ${ }^{30}$ The UNHCR Chiapas Office is also referring asylum seekers to the COMAR. Meanwhile, the INM has suspended all refugee documentation procedures while it determines how to issue the migration documents utilizing the articles contained in the Law and Regulations.

Detention procedures have not yet changed. COMAR officers continue to interview asylum applicants in detention or in the COMAR offices and UNHCR officers are providing consultation during the transition process. The issue of releasing asylum seekers while their applications are being reviewed has not yet been debated.

As a result of this abrupt transition, new ad hoc procedures are being created to replace the old ones. For example, the COMAR has taken over the eligibility process, but the INM representative is the only other government participant to date. In addition, the INM is referring all of the cases to the COMAR rather than taking on its legal responsibilities in the refugee process. These problems, combined with more fundamental questions such as who will continue to conduct the interviews and prepare the objective case information, what kind of documentation will be provided to refugees, who will provide and pay for it, etc., are in the process of being determined.

\section{Conclusions}

Considering the direct impact that this ambiguous transition in asylum procedures is having on the current refugee population and those organizations that assist refugees, it is easy to lose perspective of the broader context of refugee protection in Mexico. For example, the underlying problem is not only the inadequate Mexican legal framework and lack of implementation, but also the fact that many asylum seekers in Mexico would rather be in other countries. Those who are detained during their journey are forced to request asylum in Mexico in order to avoid being returned to their country of origin. Refugee advocates understand and respect this desire and recognize the principle of choosing one's country of asylum contained in article 14 of the Universal Declaration of Human Rights and UNHCR Executive Committee Conclusion $15 .^{31}$

This situation became more apparent after the September 11 attacks in the United States when Mexico began to heighten security measures along the southern and northern borders. On this same day, a group of Iraqi asylum seekers were detained in Tijuana, Baja California, and transferred to the Mexico City detention centre (an approximately thirty-five-hour trip by land). Due to overcrowding, the INM transferred the group of detainees to a military base in Champoton, Campeche (an approximately twenty-hour trip by land). The UNHCR was contacted and protection officers flew to the military base to conduct interviews. However, none of the asylum seekers wished to request refugee status in Mexico.

Over the course of several months, at first through UNHCR negotiations that succeeded in obtaining the release of those who had asylum applications pending in the U.S., and later through alternative procedures, the majority of the Iraqis were able to make their way to the border. Sin Fronteras received reports from several detainees that they had paid large sums of money to obtain their release, but no one wished to sign a statement or initiate a legal procedure. This experience demonstrated that finding ways to protect asylum seekers, including legal alternatives to detention, might come into conflict with people's wishes and right to choose their country of asylum.

The issue regarding the detention of asylum seekers in Mexico will have to be redebated. It is clear to refugee advocates that asylum seekers should not be in detention during the application process. Ironically, advocates may now be in a better position to pressure INM officials to release asylum seekers once they have submitted their application, because they will have a legal procedure pending rather than an application to the UNHCR office. If this were to happen, those asylum seekers wishing to continue their journey could attempt to do so, while those who desired to remain in Mexico would avoid the trauma of detention.

In the meantime, refugee advocates need to focus on projects that will ensure protection for those people who wish to apply for asylum and remain in Mexico, and to advocate for better conditions and procedures in the existing detention centres. One immediate priority is to ensure that the eligibility process remains objective, fair and non-adversarial. Other priorities include: 
- promoting reforms to the General Law on Population and the Regulations that comply with the Refugee Convention and establish more realistic timeframes and due process procedures to protect refugees;

- developing mechanisms to monitor the numbers of potential asylum applicants that are trying to reach the border or who are caught up in migration procedures in Mexico;

- continuing to coordinate with legal representatives in the United States to ensure that persons who attempt to apply for asylum along the Mexico-U.S. border are provided access to the procedure.

\section{Notes}

1. While the Mexican legal framework distinguishes between refugees and asylees, the two are used interchangeably for purposes of this article.

2. Convention on Territorial Asylum, adopted in Caracas, March 28, 1954; Convention on Diplomatic Asylum, adopted in Caracas, March 28, 1954; Cartagena Declaration on Refugees, subscribed in Cartagena de Indias, Colombia, November 22, 1984.

3. Article 42 (VI), Refugee: “ to protect a person's life, safety or freedom when he or she has been threatened by generalized violence, foreign aggression, internal conflicts, or massive human rights violations that have severely disturbed the public order in his or her country of origin and forced him or her to flee to another country [author's translation]." The Declaration of Cartagena on Refugees states: "Hence the definition or concept of a refugee to be recommended for use in the region is one which, in addition to containing the elements of the 1951 Convention and the 1967 Protocol, includes among refugees persons who have fled their country because their lives, safety or freedom have been threatened by generalized violence, foreign aggression, internal conflicts, massive violation of human rights or other circumstances which have seriously disturbed public order."

4. These statistics, compiled by the UNHCR Regional Office in Mexico City and Sin Fronteras, include family reunifications for 2001.

5. The Mexican National Migration Institute was created by decree in October 1993 as a technical agency dependent of the Interior Ministry. It is responsible for the planning, administration, enforcement, and evaluation of migration services in Mexico.

6. Statistics compiled by the UNHCR Regional Office in Mexico City, January 2002.

7. UNHCR officers ask refugees for their point of entrance, but many are unable to identify the place due to language difficulties and due to the fact that they report having travelled for several days through jungle-like areas.

8. While the UNHCR and Sin Fronteras (a Mexican NGO that provides legal and social services to refugees) are unable to systematically track the number of refugees who leave the country, these estimates are based on the number of refugees who lose contact with both offices, do not return after a year to renew migration documents, or have re-established contact after arriv- ing in other countries (e.g., refugees may recontact the offices if they are facing removal proceedings in the United States).

9. Article 212 of the Regulations of the General Law on Population grants discretion to the INM to issue an exit order to migrants instead of deporting them from the country as long as the migrant requests the exit order voluntarily or as the consequence of an immigration proceeding and if the migrant has not committed repeated violations of the law.

10. Article 166 (VII) (a) of the Regulations allows for a waiver of the deadline when "the motives for the claim came about after having entered the country." This article apparently covers refugees sur place, but does not apply to those who have missed the deadline for other reasons

11. The Mexican Commission for Refugee Aid was created by decree in July 1980 as a permanent, inter-ministerial agency. Its mission is to provide aid, protection and durable solutions to refugees in Mexico.

12. Article 167 of the Regulations.

13. Ibid.

14. Article 227 of the Regulations.

15. Article 11 (XIII) of the Law of the Federal Tribunal for Fiscal and Administrative Justice.

16. Regulatory Law in Constitutional Matters (Ley de Amparo).

17. The lack of a definition or guiding criterion to determine "inconvenient" allows administrative officers to exercise discretion that has been widely criticized for leading to arbitrary and abusive decisions. See Corcuera, Santiago, La Facultad Constitucional del Poder Ejecutivo Mexicano para Expulsar a Extranjeros del Territorio Nacional vs. El Derecho Internacional de los Derechos Humanos, paper presented to the Centre for Latin American Studies, University of Cambridge, England, June 1998.

18. Art. 166 (I).

19. Article 166 (II): "The migration authority shall take the necessary measures to ensure that the applicant remains at his disposition, until the application has been resolved [author's translation]."

20. Article 73: "The authorities who by law are authorized to act in federal, local and municipal enforcement will collaborate with migration authorities upon request, in order to enforce the dispositions of this law [author's translation].” It is important to note that military personnel, private security agents, and even fiscal authorities have been known to detain undocumented migrants.

21. Migrants from Central American members of the CA-4 agreement (Guatemala, El Salvador, Honduras, and Nicaragua) are deported to Guatemala through a bilateral agreement between Mexico and Guatemala. From Guatemala, a pilot program supported by the U.S. government assists with return to the migrant's country of origin.

22. Article 153 of the General Law on Population authorizes the National Migration Institute to grant custody of migrants in administrative detention to financially solvent individuals or institutions. Article 139(i) of the General Law on Population establishes a fine of up to 1,000 days of the Mexico City 
minimum wage, or approximately $\$ 4,5000.00$ USD, to be applied if the individual or organization loses contact with the migrant.

23. Article 7 (VX), Agreement to Establish Norms for the Functioning of the Migration Centres of the National Migration Institute, Federal Registry, November 26, 2001.

24. Article 7 (XIII), Agreement to Establish Norms for the Functioning of the Migration Centres of the National Migration Institute, Federal Registry, November 26, 2001.

25. Article 6, Agreement to Establish Norms for the Functioning of the Migration Centres of the National Migration Institute, Federal Registry, November 26, 2001.

26. Interview with the National Director of Migration Inspection and Verification, Mexico City, March 14, 2002.

27. The most documented case involves a group of migrants from India who were deported from Mexico to Guatemala and redetained there. After approximately six additional months in detention, one of the migrants, Kanu Patel, hung himself. As a result of this incident, the Guatemalan National Migration Forum (MENAMIG) sued the Guatemalan Migration Directorate. The remaining migrants were released from detention and some tried to make their way north again, only to be redetained in Mexico.

28. The Mexican Migration Forum, Foro Migraciones, conducted over three hundred interviews in eight different centres and is currently preparing the results for publication.

29. See Juan Carlos Romero Puga, "En los sótanos de Migración," Milenio Semanal, June 11, 2001; Luis Alegre, "Ilegales en México: sin sueño y sin cupo," Reforma, August 12, 2001; and Alonso Urrutia, "Viaje hacia ninguna parte," La Jornada, September 20, 2001.

30. This is an unusual ad hoc procedure considering that one governmental agency is granting custody to another.

31. Universal Declaration of Human Rights, Article 14: 1. "Everyone has the right to seek and to enjoy in other countries asylum from persecution," ExCom Conclusion No. 15 (XXX) - 1979) (h) (iii): "The intentions of the asylum-seeker as regards the country in which he wishes to request asylum should as far as possible be taken into account."

Sin Fronteras, I.A.P. is a Mexican non-governmental organization dedicated to promoting and defending the human rights of migrants through advocacy and social and legal assistance. Programs include social and legal services for refugees and migrants, education and training, and advocacy work on a national and regional level. Gretchen Kuhner is a U.S. trained lawyer who has worked with Sin Fronteras since 1998.

(C) Gretchen Kuhner, 2002. This open-access work is licensed under a Creative Commons Attribution-NonCommercial 4.0 International License, which permits use, reproduction and distribution in any medium for non-commercial purposes, provided the original author(s) are credited and the original publication in Refuge: Canada's Journal on Refugees is cited. 